\title{
On the right to not cite, and not being deceivingly lynched and libeled because of it
}

Dear editors,

This is a letter of response to the text Mr. Francisco Javier Martínez sent to the editorial office of História, Ciências, Saúde - Manguinhos regarding our paper "Colonial scientificmedical documentary films and the legitimization of an ideal state in post-war Spain." In that text, Mr. Martínez claims that our paper "may" lead the readers of Manguinhos "to believe ... that this is the first investigation that uses medical documentaries on the Spanish African colonies as historical sources [and] that it is the first study framing those sources within the ideology and symbolic representations of the early Francoist regime." Later on, he uses this argument (1) to demand the citation of two of his publications, and (2) to accuse us, the paper, and the undersigned Carlos Tabernero, Isabel Jiménez-Lucena, and Jorge Molero-Mesa, of malpractice. We want to thank the editors for the opportunity they are granting us to respond on a back-to-back basis to Mr. Martínez's complaints, arguments, and accusations.

As Mr. Martínez says, he once "had a close professional relation" with us. Yet he might have forgotten some facts regarding that professional relationship, and their extremely pertinent chronology. The first author of the paper, Carlos Tabernero, started working with the mentioned film sources in February 2008, under the supervision of the third author of the paper, Jorge Molero-Mesa, with the aim of producing the former's master's thesis. This research was openly carried out in the context of a project funded by what was then the Spanish Ministry of Education and Science (reference HUM2006-12278-C03-03), titled "Medicina y regulación social en la España del siglo XX: pensamiento subalterno y colonialidad del saber científico en torno a la etnia y a la clase," which lasted from 2006 to 2009. Mr. Martínez was part of that project.

In June 2009, all members of the project, belonging to three groups of historians of medicine from Barcelona, Madrid, and Málaga, and obviously including Mr. Martínez, gathered in Málaga for a research meeting called "Jornadas de Trabajo I+D HUM2006-12278: De subalternidades y medicina. Herramientas para el análisis de la regulación social en la España contemporánea." In that meeting, Carlos Tabernero gave a talk titled "Discursos y representaciones médico-sanitarias en el cine documental de la posguerra española (19391950)," in which he shared with the rest of the project contributors the state and progress of his work with the abovementioned sources. The aim was to draft and discuss suggestions. Mr. Martínez had, as all others attending, the chance to comment. He did not mention, though, that he had been or was then working with those same sources, as would have been, we believe, appropriate. In that same meeting, he gave another talk on a completely different topic and supported by completely different sources.

Later on, at the end of that same year, we were all dumbfounded when the Uriach Prize was announced: we learned then, and not before, that Mr. Martínez's had been working with 
those same film sources. We were so surprised by the title of the winning article, given the fact that we had presented our research shortly before, that we asked a member of the 2009 jury about it, prior to the publication of Mr. Martínez's work, wondering if that research in fact bore any resemblance to the research presented by Carlos Tabernero several months earlier in Málaga, only to confirm it. Our query was essentially stirred by the fact that Mr. Martínez knew about our research as, we insist, it was carried out openly and with the desire to share. We were left wondering why Mr. Martínez had not shared his own research with the rest of the members of the project. If Mr. Martínez had started working with these sources before February 2008, or even afterwards but prior to Carlos Tabernero's talk in the Málaga meeting, we never knew.

Later in 2010, Carlos Tabernero's master's thesis, supervised by Jorge Molero-Mesa, was duly presented and successfully defended. And, in due time that same year, it was uploaded (i.e., published online) in the digital archive of the Autonomous University of Barcelona (http://ddd.uab.cat/record/64787?ln=ca), with the title "Discursos y representaciones médicosanitarias en el cine documental colonial español de la posguerra (1939-1950)." Despite its "easy access ... on the internet," to borrow Mr. Martínez's words, he must have accidentally missed our citing his awarded paper then (p.30 and 40) and our including a reference to his work "in the bibliography at the end of the text" (p.50), even if it was to state that, as he also says, we did indeed not "share [his] methodology and interpretations."

Interestingly, in his 2012 paper in the journal Awraq, he did not cite or make any reference to our 2010 online publication. He may have then considered that it was not relevant to his analytical frame. We did and do respect that, that is, his right to not cite us (or anyone else, by the same token). And therefore, we did not try to force the citation of our work with any letter to the editors of Awraq.

That same year of 2012, we published a chapter, signed by the three of us, titled "Film, medicine and empire: inclusion-exclusion practices and discourses in Spanish medical-colonial documentaries of the 1940s," in the book The circulation of science and technology: proceedings of the 4th International Conference of the ESHS, Barcelona, November 2010. As clear from the title of the chapter, our aims, methodologies, and analytical frames had already fully diverged from Mr. Martínez's by the time of the ESHS Conference, in November 2010; we were then clearly "suggest[ing] different interpretations about Francoism and medical documentaries on Spanish African colonies," as he acknowledges in his letter; indeed, we were focusing on thoroughly exploring the associated inclusion-exclusion dynamics.

With all this in mind, we want to markedly stress that there is nothing in our paper suggesting that we claim or want to claim to be the first to deal in historical terms with Spanish medical-colonial sources. We did not then and have never claimed to be the first ones to use these sources or apply them to the Franco regime's communication strategies. In fact, we duly make reference to two secondary sources that Mr. Martínez also cites in his papers and that were published years before we ever considered the possibility of doing research in this field: M.D.F. Fígares Romero de la Cruz's book La colonización del imaginario: imágenes de África, published in 2003, and Pere Ortín and Vic Pereiró's book Mbini: cazadores de imágenes en la Guinea colonial, published in 2006. We cite them because we deem them 
relevant to our work. At the same time, we claim our right to not cite works that we do not deem relevant to our analysis, most especially if the context is a research paper that does not aim to undertake a comprehensive bibliographic appraisal/review of the topic. Mr. Martínez should also note that Manguinhos is a peer-reviewed journal, and our referees, who, judging by their comments and suggestions, were highly knowledgeable of the topic and its associated research, did not point out to us the need to cite his work.

Last, but certainly not least, on top of all this, Mr. Martínez's suggestion that our not citing him amounts to malpractice is not only preposterous and outrageous, but downright unacceptable. Indeed, using his citations from the American Historical Association and the AHISTCON, and as stated above: (1) we did not deem his work "distinctive" enough for our analytical frame, as we did not aim to discuss his interpretations, so we have the right to not cite it; (2) given the abovementioned facts concerning the first years of this research, we neither understand nor tolerate his references to "intellectual integrity," "honesty," and "reliability," which he quotes from the American Historical Association Statement on Standards of Professional Conduct; in this sense, while Mr. Martínez makes reference to the fact that "Scholarship flourishes in an atmosphere of openness and candor, which should include the scrutiny and public discussion of academic deception" (our emphasis), he did not grant us, when we were collaborators in the aforesaid research project, the required openness and candor that he claims for himself; and (3), just to make it even clearer, there is nothing in our paper remotely resembling Mr. Martínez's analytical formulations.

In all, Mr. Martínez is accusing us now, and by logical extension our referees and the journal, as those in charge of scrutiny for deception, of somehow deliberate and/or neglectful malpractice. By doing this, we believe Mr. Martínez is trying to force the citation of his work while making everybody, including the readers, editors, and publishers of Manguinhos, spend time paying attention to him instead of devoting ourselves to our teaching and research. If these letters have been published in the end, we thus regret it, and disclaim any responsibility for it.

Carlos Tabernero, Isabel Jiménez-Lucena, and Jorge Molero-Mesa March 27, 2017 